\title{
Zamki mazowieckie a architektura zakonu krzyżackiego. Rekapitulacja
}

\section{Mazovian castles and architecture of the Teutonic Order. A recapitulation}

Zarys treści. Artykuł dotyczy problematyki związków między architekturą obronno-rezydencjonalną zakonu krzyżackiego a zamkami mazowieckimi. Autor analizuje dotychczasowe poglądy na temat korelacji artystycznych między dominium Zakonu a Mazowszem, konfrontując je zarówno ze studiami nad architekturą zachowanych obiektów, jak i źródłami pisanymi oraz wynikami najnowszych badań terenowych. Na tej podstawie wysnuwa nowe wnioski odnośnie ewentualnych wzajemnych relacji architecturae militaris obu państw, jak też przewartościowuje starsze poglądy na prezentowany temat. Zdaniem autora główny problem w badaniach nad związkami krzyżacko-mazowieckimi w dziedzinie architektury (nie tylko obronnej) to brak liczniejszych wzmianek źródłowych, potwierdzających obecność muratorów z terenów państwa zakonnego na obszarze Mazowsza w XIV-1. połowie $\mathrm{XV}$ wieku. Autor podnosi też kwestię powszechności niektórych elementów architektury zamkowej, uznawanych za typowo krzyżackie (np. wieloboczne wieże główne), wskazując na możliwość przeniesienia tego typu rozwiązań także z Królestwa Polskiego. Artykuł porusza także problematykę zwierzchnictwa nad warsztatami budowlanymi w Prusach, ich funkcjonowania i kompetencji. W dotychczasowej literaturze przedmiotu badacze silnie akcentowali brak w hierarchii zakonnej urzędników, odpowiedzialnych za wznoszenie budowli obronnych. Podczas realizacji swych siedzib Zakon miałby się posługiwać warsztatami pochodzącymi z większych ośrodków miejskich, które dostosowywały swą działalność do potrzeb zleceniodawcy, posługując się wszakże rozwiązaniami wypracowanymi i upowszechnionymi w środowisku artystycznym Niżu Środkowoeuropejskiego. Wyniki nowszych badań wskazują jednakże na możliwość dużo większej ingerencji i kontroli urzędników krzyżackich w proces budowlany, jak też sugerują istnienie rzemieślników silniej niż się to dotychczas wydawało, związanych ze strukturami Zakonu.

Stowa kluczowe: zakon krzyżacki, zamki, Mazowsze, związki kulturowe, architektura obronna, księstwo mazowieckie. 
W 2007 roku Leszek Kajzer opublikował na łamach Archaeologia Historica Polona artykuł, poświęcony problematyce wpływów budownictwa obronnego zakonu krzyżackiego na zamki Niżu Polskiego (Kajzer 2007, s. 259-272). Ten wybitny badacz architektury obronno-rezydencjonalnej skonstatował wówczas, że „choć motyw wpływu architektury zamków krzyżackich na sąsiednie warownie pojawia się prawie we wszystkich pracach poświęconych ich architekturze militarnej, to problematyka ta nie została dokładnie zbadana" (Kajzer 2007, s. 260). Dalej L. Kajzer zauważył, że problem ten w dotychczasowej literaturze przedmiotu traktowany był niekiedy ekstremalnie, z jednej strony bowiem pojawiały się stanowiska mówiące wprost o szerokiej akulturacji rozwiązań architektonicznych, stosowanych w zamkach krzyżackich, z drugiej zaś niektórzy badacze całkowicie negowali możliwość oddziaływania architecturae militaris państwa krzyżackiego na tereny sąsiednie. Leszek Kajzer przyjął w tej kwestii stanowisko umiarkowane. Nie negując całkowicie możliwości migracji warsztatów i rozwiązań stosowanych w architekturze obronnej Krzyżaków na obszar sąsiednich państw, wskazał jednocześnie potrzebę pogłębionych studiów na ten temat, w jego opinii dotychczas nie podejmowanych w szerszym zakresie. Niniejszy tekst wychodzi naprzeciw tak zaznaczonym potrzebom badawczym, a jego celem będzie prześledzenie domniemanych związków między architekturą obronną państwa zakonnego a zamkami mazowieckimi, których rozwój przypadł przede wszystkim na 2. połowę XIV i XV stulecie.

W tym miejscu należy zaznaczyć, że zazwyczaj zbiorcze określenie Mazowsze odnosi się do różnych ziem, o odmiennych warunkach topograficznych, glebowych, wreszcie odmiennej sytuacji geopolitycznej. Niemniej terytoria te mogą być rozumiane en masse jako specyficzne środowisko architektoniczne i tak też zostaną przeze mnie potraktowane. Mazowsze, jako część władztwa piastowskiego, mając najdłuższą granicę z zakonem krzyżackim, a także rozliczne kontakty polityczne i handlowe, jawi się jako obszar niejako predestynowany do przejmowania wzorców kulturowych bardziej rozwiniętego sąsiada. W intersującej mnie kwestii architektury obronnej pogląd ten ma dodatkowo mocne ugruntowanie w literaturze przedmiotu (tu przede wszystkim: Galicka 1963, s. 118; 1968, t. 1, s. 87-90; Kunkel 1995, s. 89-90; 2006, s. 133; Zagrodzki 1996, s. 42; Galicka, Sygietyńska 2006, s. 541). Wpływy architektury zakonnej na zamki mazowieckie były rozpatrywane na dwóch płaszczyznach. Po pierwsze, badacze, analizując formę i technikę budowy tych ostatnich, dostrzegali możliwość zapożyczenia przez działające na Mazowszu warsztaty gotowych rozwiązań, stosowanych w państwie zakonnym. Po drugie, posługując się, nikłymi zresztą, wzmiankami w źródłach pisanych, próbowano udowodnić bezpośrednie zaangażowanie budowniczych krzyżackich w inwestycje zamkowe na Mazowszu.

Jeśli chodzi o podstawową dla historii sztuki i architektury metodę badawczą, jaką jest analiza porównawcza, to wśród obiektów mazowieckich można jej poddać, 
niestety, zaledwie kilka obiektów, zachowanych w mniejszym lub większym stopniu w formie kubaturowej lub poznanych w wyniku badań archeologicznych. Do dnia dzisiejszego przetrwały częściowo mury zamków w Ciechanowie, Czersku, Liwie, Płocku i Rawie Mazowieckiej (Galicka, Sygietyńska 2006, s. 541). Z arcybiskupiego zamku w Łowiczu przetrwały nikłe relikty (Nierychlewska 2013, s. 242), zaś obronna siedziba biskupów płockich w Pułtusku została gruntownie przekształcona po ostatniej wojnie światowej (Pela 2016, s. 15-16). Zamek w Gostyninie nie istnieje, jedynie fragmenty dolnych kondygnacji jego wieży zachowały się w murach dawnego kościoła ewangelickiego, zbudowanego w 2. ćwierci XIX stulecia, w latach 1825-1840, w stylu neogotyckim według projektu Hilarego Szpilowskiego (Pietrzak 2012, s. 9). W 2009 roku w sąsiedztwie budynku wzniesiono stylizowany na budowlę obronną obiekt hotelowy, ostatecznie zamykając możliwość badań wzgórza zamkowego. Podstawowe etapy rozwoju gostynińskiego castrum znamy dzięki wynikom eksploracji terenowych Janusza Pietrzaka (2012, s. 9-44). Zamek warszawski, znacznie przekształcony w wyniku przebudów XVI- i XVII-wiecznych, następnie zaś niemal całkowicie zniszczony podczas II wojny światowej, zachował się w nikłej części (przyziemie wieży grodzkiej i część piwnic), znany jest natomiast dzięki badaniom archeologicznym i archiwalnym (ostatnio por. - Bocheńska 2017, s. 147-160). Natomiast zamek sochaczewski przetrwał szczątkowo w formie, jaką nadały mu przekształcenia nowożytne, przede wszystkim z czasów starosty sochaczewskiego Stanisława Radziejowskiego (Kajzer, Olszacki 2011, 55-62; Nierychlewska 2013, s. 348-349). O jego formie średniowiecznej wiemy bardzo mało. Informacje o innych zamkach mazowieckich, jak choćby w Wyszogrodzie czy Wiźnie, czerpiemy głównie ze źródeł pisanych (Galicka, Sygietyńska 2006, s. 537; Olszacki, Różański 2018, s. 204-207).

Mimo relatywnie słabego stanu zachowania substancji zabytkowej, w odniesieniu do tak zarysowanego przedmiotu badań przeprowadzano liczne studia komparatystyczne, przede wszystkim analizując badane obiekty pod kątem ich zależności od architektury militaris dwóch dominujących politycznie i gospodarczo sąsiadów - państwa zakonnego w Prusach i Królestwa Polskiego. Większość badaczy podkreślała charakterystyczne dla Mazowsza warunki topograficzne oraz brak kamiennego budulca, co miałoby zbliżać architekturę księstwa przede wszystkim do północnoeuropejskiego kręgu budownictwa ceglanego, w którym pierwszoplanową rolę pełniły w XIV stuleciu warsztaty pracujące na zlecenie zakonu krzyżackiego, oddziaływujące następnie na obszar Niżu Polskiego oraz ziemie mazowieckie (Kunkel 1995, s. 87; Galicka, Sygietyńska 2006, s. 540). Opisywane budowle obronne, prócz samej techniki wykonania ich murów (cegła na wysokim, kamiennym podmurowaniu, zastosowanie technologiczne i dekoracyjne cegły zendrówki), miałyby łączyć ze strefą oddziaływania architektury zakonnej także poszczególne elementy obronne i mieszkalne (Galicka, Sygietyńska 2006, s. 537). 
Związki z architekturą zakonu krzyżackiego zaznaczano już w przypadku najstarszej zabudowy murowanej zamku warszawskiego (ryc. 1). Być może już za czasów Trojdena I († 1341) lub też jego syna Kazimierza I († 1355) wzniesiono w południowo-wschodniej części majdanu grodu warszawskiego, na zboczu skarpy wiślanej, ceglaną wieżę (ryc. 1). Obiekt posadowiony był na rzucie zbliżonym do kwadratu o boku długości $12,4 \mathrm{~m}$, przy grubości murów w partii przyziemia około $3 \mathrm{~m}$. Budowla, wzmocniona przyporami w narożach i w osiach ścian, posiadała pierwotnie przynajmniej trzy kondygnacje, zaś przy jej północnym boku zlokalizowano czworoboczny aneks z cylindrycznym pomieszczeniem o średnicy około 2,5 m, w dolnej kondygnacji mieszczącym najpewniej studnię, wyżej zaś ciąg komunikacyjny. Opisywana wieża, zwana pierwotnie Wielką, później zaś Grodzką, chroniona była przez obwód obronny (wały), w którym znajdował się murowany budynek bramny, kryjący urządzenia zwodzonego mostu, przerzuconego nad fosą. Być może wieży towarzyszyła też drewniana zabudowa mieszkalna (podsumowanie stanu wiedzy o początkach zamku warszawskiego - por. Bocheńska 2017, s. 147-160).

Postrzeganie warszawskiej turris jako realizacji powstałej w kręgu architektury obronnej zakonu krzyżackiego należy rozpatrywać niewątpliwie na gruncie podnoszonych wielokroć związków architektury - przede wszystkim murów miejskich (Widawski 1970, s. 245; Gieysztor 1981, s. 73; Mroczko 1986, s. 17; Kunkel 2006, s. 108; Sieradzan 2008, s. 581), ale też na przykład kolegiaty pw. św. Jana (Zagrodzki 1996, s. 42), a także kamienic (Kunkel 2006, s. 104; 2007, s. 212) - oraz układu urbanistycznego Warszawy z miastami w państwie zakonu krzyżackiego (Zagrodzki 1956, s. 225-265; Mroczko 1986, s. 15). Robert Kunkel nazwał wręcz Warszawę swego rodzaju „toruńskim emporium” (Kunkel 2006, s. 100). Zarówno sam układ lokacyjny, jak też sposób konstrukcji najstarszego odcinka murów obronnych miast wskazywał nieodparcie na pruskie pochodzenie zasadźców oraz w sposób oczywisty zdawał się wytyczać dalszą drogę dociekań w przypadku najstarszych murowanych elementów zabudowy warszawskiej siedziby książęcej. Aleksander Gieysztor widział odległe analogie warszawskiej wieży w „budowlach obronnych nad dolną Wisłą, skąd pochodzić mogli jej budowniczowie" (Gieysztor 1981, s. 64). Niemniej wieże mieszkalne nie należą do częstego typu budowli, powstałych z inicjatywy krzyżackiej. Jednym z nielicznych przykładów jest obiekt, znany jako Wieża Mestwina lub Mściwoja w Chełmnie (ryc. 2), zachowany w obrębie klasztoru Sióstr Miłosierdzia, dawniej cysterek, następnie benedyktynek (Mroczko 1974, s. 287, 295). Robert Kunkel przyjął warunkowo hipotezę A. Gieysztora, dostrzegając możliwość powiązań warsztatowych wieży warszawskiej właśnie z budowlą w Chełmnie (Kunkel 2007, s. 212). Ta ostatnia uchodzi za jeden z nielicznych reliktów chełmińskiego zamku, należącego do najwcześniejszych siedzib komturskich w Prusach, co jednak nie zostało nigdy w przekonywujący sposób udowodnione. Wyniki nowszych badań wskazują 


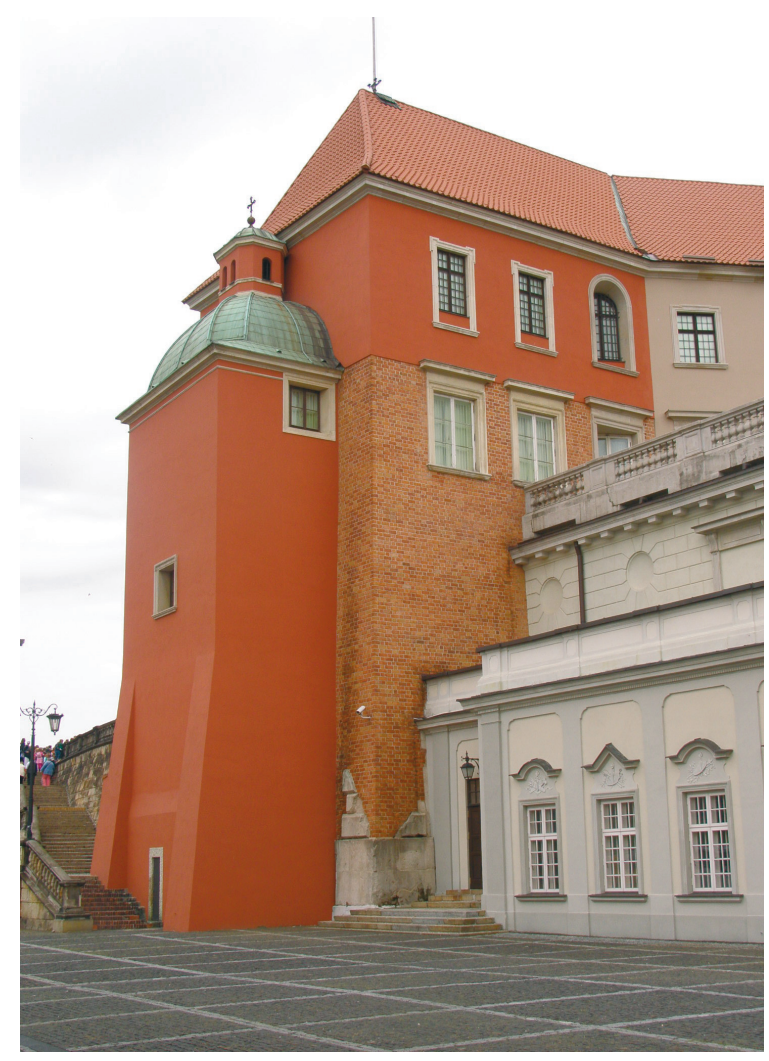

Ryc. 1. Warszawa. Zamek Królewski - tzw. Wieża Grodzka (fot. P. Lasek)

Fig. 1. Warsaw. Royal Castle - the so-called Grodzka Tower (photo by P. Lasek)

wręcz, że siedziba komtura chełmińskiego znajdowała się nie w samym Chełmnie, a w pobliskim Starogrodzie (Wasik 2016, s. 268-271). Ponadto warszawską wieżę różni od obiektu w Chełmnie także znajdujący się przy północnym boku budowli czworoboczny aneks. Dodatkowo magna turris w Warszawie uległa znacznej destrukcji podczas ostatniej wojny światowej. Zachowały się jedynie mury przyziemia, w związku z czym trudno wysuwać jakiekolwiek wiążące tezy co do jej ewentualnych korelacji warsztatowych. Lepiej natomiast udokumentowane i chyba słuszne jest łączenie jej z wpływami pomorskimi lub krzyżackimi tzw. Dworu Wielkiego (ryc. 3), wzniesionego w obrębie warszawskiej siedziby książęcej w początkach XV wieku przez Janusza I Starszego (Grzybkowski 1979, s. 215; Gieysztor 1981, s. 64; Mroczko 1986, s. 14; Kunkel 2006, s. 119). Owa siedziba książęca wprawdzie uległa zniszczeniu podczas ostatniej wojny światowej, jednakże dokonane w 1921 roku przez Kazimierza Skórewicza odsłonięcie i zadokumentowanie fragmentu elewacji od strony dziedzińca zamkowego umożliwiło częściowe odtworzenie jej fasady oraz dało asumpt do przeprowadzenia właściwych analiz badawczych (Dąbrowski 1949, s. 226-236; Król 1971, s. 15-21; Lileyko 1995, s. 248; Kąsinowski 2001, s. 64-65; Oborska 2001, s. 88-89). 


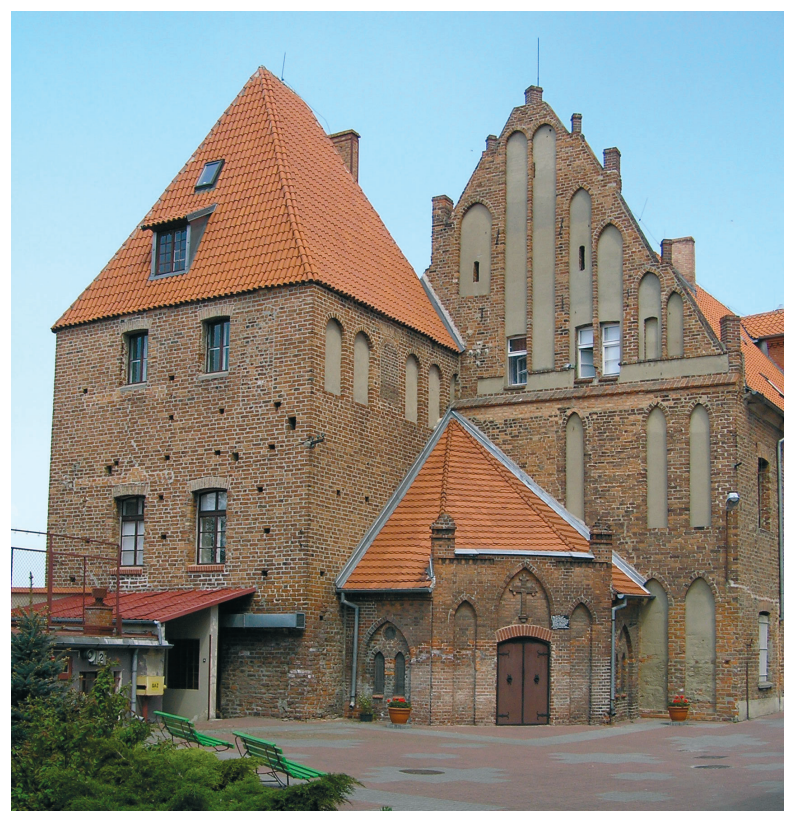

Ryc. 2. Chełmno. Tzw. Wieża Mestwina (https://commons.wikimedia.org/w/index. php?curid=781252; Pko - praca własna, CC-BY 2.5)

Fig. 2. Chełmno. The so-called Mestwin Tower (https://commons.wikimedia.org/w/ index.php?curid=781252; Pko - own work, CC-BY 2.5)

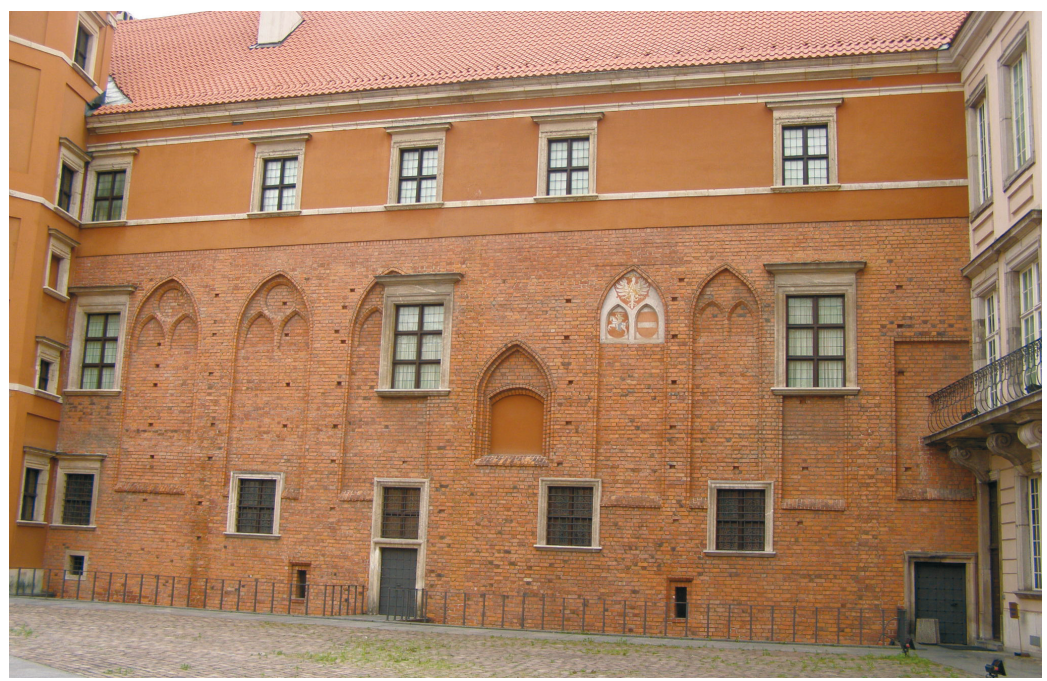

Ryc. 3. Warszawa. Zamek Królewski - tzw. Dwór Wielki; zrekonstruowana fasada (fot. P. Lasek)

Fig. 3. Warsaw. Royal Castle - the so-called Great Mansion; reconstructed facade (photo by P. Lasek) 
Wśród pozostałych zamków mazowieckich jedynie poszczególne elementy ich zabudowy rozpatrywane były w kontekście związków z architekturą zakonu krzyżackiego. Chodzi tu przede wszystkim o wieloboczne wieże, które spotykamy na zamkach w Płocku i Rawie Mazowieckiej, a także Wyszogrodzie. Jeśli chodzi o zamek płocki, to w świetle dotychczasowych badań archeologicznych jego kreację rozpoczęto na przełomie XIII i XIV wieku, a domniemanym fundatorem nowego, murowanego obiektu na miejscu wcześniejszego grodu był książę Bolesław $\mathrm{II}^{1}$. Posadowiony na kamiennym fundamencie mur z cegły w wątku tzw. gotyckim, obiegający cały obszar tzw. Wzgórza Tumskiego, połączył nadbudowaną na starszej wieży mieszkalnej ceglaną wieżę obronną, tzw. Wieżę Zegarową i nową wieżę bramną (Wielką, późniejszą tzw. Szlachecką), w partii przyziemia i piętra posadowioną na rzucie czworoboku zbliżonego do kwadratu, górą zaś ośmioboczną (ryc. 4). Ostrołukowy przejazd bramny, częściowo obramowany kamieniem, pierwotnie mieścił wrota, blokowane drewnianym ryglem. Od zewnętrz otwór bramny ujęty został we wnękę, służącą jako schowanie dla mostu zwodzonego. Wieża bramna była pierwotnie dużo wyższa od niedalekiej Wieży Zegarowej (dlatego zwana Wielką). Poprzedzał ją most, przerzucony nad fosą, najpewniej suchą. W obrębie murów zamku usytuowana była katedra płocka, budynki i kościół opactwa benedyktyńskiego oraz siedziba książęca, znajdująca się jednakże - wbrew pojawiającym się niekiedy w literaturze informacjom - w południowej części kompleksu (Lasek 2017, s. 180-184). Tak ukształtowane założenie Kazimierz Wielki obwiódł drugim murem obronnym, z budowlą bramną od północnego zachodu, zapewne wieżową (Polak 2011, s. 368-373; Lasek 2017, s. 80).

Kreację castrum w Rawie Mazowieckiej rozpoczął najpewniej jeszcze Siemowit III, a finalizacja przedsięwzięcia przypadła już na lata panowania jego syna, Siemowita IV (Nierychlewska 2013, s. 308). Realizacja ta, o największej wśród zamków mazowieckich powierzchni $\left(4200 \mathrm{~m}^{2}\right)$, założona została na rzucie czworoboku o wymiarach 64×66 m (ryc. 5). Wjazd wiódł przez trójkondygnacyjną wieżę bramną, zlokalizowaną na osi południowego muru obronnego. Cały północny bok zamku zajmował piętrowy pałac na rzucie wydłużonego czworoboku. Drugi murowany budynek położony był między bramą a południowo-wschodnim narożnikiem budowli. Pozostała zabudowa dziedzińca była drewniana. W południowo-zachodnim narożu stanęła wieża główna, u podstawy cylindryczna, górą ośmioboczna, podobnie jak mury obwodowe wzmocniona przyporami. Tak ukształtowane założenie funkcjonowało bez większych zmian także po inkorporacji ziemi rawskiej do Królestwa Polskiego.

$\mathrm{Na}$ związki opisywanego typu wież z architekturą zakonu krzyżackiego wskazywał onegdaj w przypadku zamku rawskiego Andrzej Grzybkowski (1979, s. 210-215), ostatnio zaś Wiesław Sieradzan (2008, s. 581) i Anna Nierychlewska (2013, s. 86-87). Andrzej Grzybkowski, analizując układ zamku książęcego na tle

${ }^{1}$ Ostatnio taką atrybucję poczyniła Agnieszka Teterycz-Puzio (2015, s. 93). 
Ryc. 4. Płock. Zamek - tzw. Wieża Szlachecka (fot. J. Kłos; Zbiory Fotografii i Rysunków Pomiarowych Instytutu Sztuki PAN, nr inw. 19649)

Fig. 4. Płock. Castle - the so-called Nobilty Tower (photo by J. Kłos, The Collection of Photographs and Measurement Drawings of the Institute of Art of the Polish Academy of Sciences, inv. No. 19649)

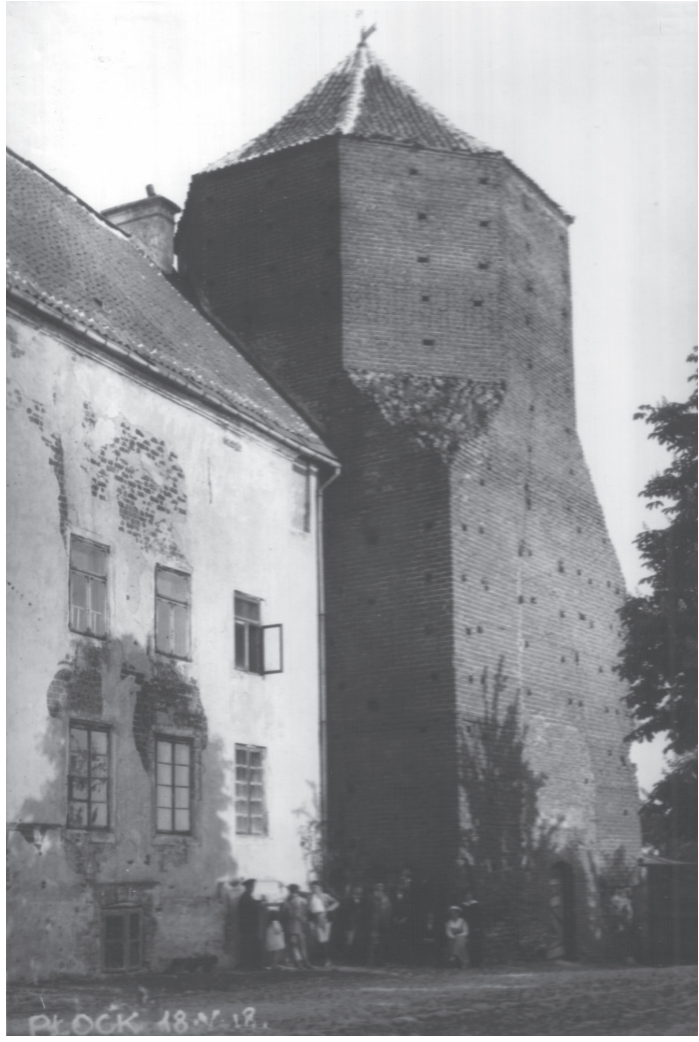

budownictwa obronnego Niżu Polskiego i państwa zakonu krzyżackiego w Prusach stwierdził: „wydaje się, że prawie nie spotykane na południu ośmioboczne wieże nizinnych zamków polskich są ściśle uzależnione od krzyżackich" (Grzybkowski 1979, s. 215). Badacz, jako potencjalne analogie, wymienia wieże główne zamków w Toruniu i Radzyniu Chełmińskim, później także Brodnicy i Człuchowie. Wedle A. Grzybowskiego także długi, trójdzielny pałac, który stał się w XV wieku typowym elementem mazowieckich zamków książęcych (Warszawa, Czersk, Liw, Ciechanów), wzorowany był na ,,budynkach administracyjno-mieszkalnych warowni zakonnych i biskupich państwa krzyżackiego" (Grzybkowski 1979, s. 215). Tu jednakże autor nie podaje żadnych konkretnych analogii. Dużo bardziej ostrożna w nakreślaniu zależności architektury zamku w Rawie od założeń zakonu krzyżackiego jest natomiast A. Nierychlewska. Wprawdzie wymienia ona oktagonalne wieże główne zamków w Toruniu, Radzyniu Chełmińskim (ryc. 6), Człuchowie i Brodnicy jako potencjalne analogie do rozwiązania rawskiego, lecz zauważa przy tym, że układ zamku rawskiego nawiązuje raczej do rozwiązań przestrzennych nizinnych zamków kazimierzowskich, jak na przykład Łęczyca, Inowłódz, Konin czy Kruszwica (Nierychlewska 2013, s. 87). Należy 


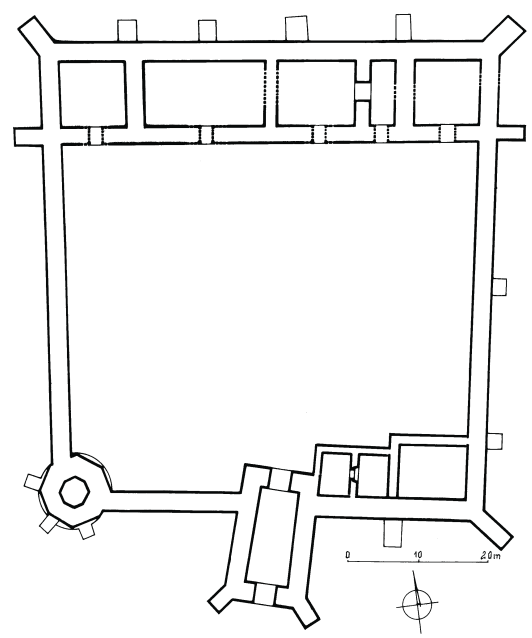

Ryc. 5. Rawa Mazowiecka. Zamek - rzut budowli w XV-XVI wieku; częściowa rekonstrukcja (rys. R. Kunkel; Zbiory Fotografii i Rysunków Pomiarowych Instytutu Sztuki PAN, nr inw. RP14631)

Fig. 5. Rawa Mazowiecka. Castle - plan of buildings in the $15^{\text {th }}-16^{\text {th }}$ centuries; partial reconstruction (drawing by R. Kunkel, The Collection of Photographs and Measurement Drawings of the Institute of Art of the Polish Academy of Sciences, inv. No. RP14631)

przyznać rację badaczce, zauważając jednocześnie, że w przypadku krzyżackich zamków w Toruniu i Radzyniu Chełmińskim wieże ośmioboczne ulokowane były wewnątrz murów założeń, podczas gdy w Rawie Mazowieckiej budowlę taką usytuowano w narożu obwodu, zapewniając tym samym możliwość obrony flanki. Natomiast w Płocku mamy do czynienia z realizacją pełniącą pierwotnie funkcję wieży bramnej. Powyższe konstatacje każą ponownie rozważyć genezę tego typu rozwiązań w architekturze zarówno zamków Kazimierza Wielkiego, jak i mazowieckich.

W dotychczasowych badaniach najbliższe związki z architekturą zakonu krzyżackiego dostrzegano jednakże w założeniach, których powstanie przypisuje się Januszowi I Starszemu. Na sformułowanie tej sugestywnej hipotezy niewątpliwie miały wpływ wyniki badań Izabelli Galickiej nad architekturą świecką wznoszoną za panowania tego księcia. Wedle badaczki „liczne i świetnie zorganizowane” warsztaty krzyżackie, wobec spadku inwestycji zakonu po jego klęsce na polach Grunwaldu, szukały zatrudnienia, w tym na ziemiach Królestwa Polskiego i na południowo-wschodnim Mazowszu, gdzie Janusz I ,wprowadzając trwały budulec na teren swej dzielnicy posłużył się doświadczonymi muratorami pruskimi rozwijał szeroką akcję budowlaną" (Galicka 1968, t. 1, s. 87). Takim muratorem pruskim miał być Niklos, który wspomniany został we wpisie znajdującym się 
w „Metryce Księstwa Mazowieckiego”, powstałym między 1417 a 1429 rokiem². Podano w nim: „Ponadto, po sporządzeniu rozliczenia z Niklosem, murarzem, w sprawie prac przy zamkach Ciechanów i Liw, pozostał panu zobowiązany na 57 kop [zapewne groszy - przyp. P. L.], o ile przypadkiem przez inne wymierzenie nie okazałoby się inaczej" (Item facta racione cum Niklos muratore super laboribus Czechanow et Liw castrorum, mansit domino obligatus LVII sexagenas, nisi forsan per aliam mensuracionem aliter invenirent - por. Metryka, t. 1, nr 8, s. 3)3. Wedle S. Pazyry wspominana w kontrakcie kwota stanowiła wynagrodzenie Niklosa „za jakieś prace murarskie” (Pazyra 1976, s. 249). Oznaczałoby to, że Niklos nie wykonał swego zadania, w związku z czym musiał oddać pieniądze księciu. Jednocześnie S. Pazyra skonstatował, że „ta niewielka stosunkowo kwota nie może być uważana w żadnym wypadku jako zapłata za zbudowanie dwóch zamków" (Pazyra 1976, s. 249). Ryszard Małowiecki zauważył jednak, że zaznaczona w rozliczeniu suma (57 kop, a więc 3420 grosze) nie jest wcale małą, i wystarczyła na pokrycie kosztów wzniesienia przynajmniej 1400-1500 m³ muru (Małowiecki 1992, s. 77-79). Inaczej cytowany wpis w „Metryce Księstwa Mazowieckiego” rozumiała I. Galicka, która uważała, że murator Niklos był najpewniej wysokiej klasy specjalistą, sprowadzonym przez księcia „,z terenów Prus lub Pomorza Wschodniego" (Galicka 1968, t. 2, s. 20). Wedle badaczki dysponował on rozległą wiedzą inżynieryjną i doskonale opanował rzemiosło murarskie. Potrafił umacniać podmokły teren specjalnym drewnianym rusztowaniem poziomym, mury wznosił na wysokim kamiennym podmurowaniu, wreszcie w partiach murów ceglanych stosował - zaczerpnięty zapewne $\mathrm{z}$ budownictwa państwa zakonnego w Prusach - motyw romboidalnej dekoracji z cegły glazurowanej o powtarzającym się module boku z sześciu główek. W optyce badaczki Niklos jawił się nie jako mistrz murarski, lecz raczej architekt-budowniczy, rezydujący przy dworze Janusza I (Galicka 1968, vol. 1, s. 81; Galicka 1984, s. 69). Warto przy tym zaznaczyć, że Galicka nie widziała podstaw, pozwalających pewnie łączyć postać enigmatycznego Niklosa z Niclausem Fellensteinem, choć oczywiście dostrzegała potencjalną atrakcyjność takiej hipotezy (Galicka 1968, vol. 1, s. 88)4.

Zdaniem I. Galickiej wspomniana wzmianka źródłowa w „Metryce Księstwa Mazowieckiego" wskazuje na to, że Niklos miał rozpocząć dla Janusza I budowę zamków w Ciechanowie i Liwie, a prawdopodobnie również w Czersku. Co więcej, wedle badaczki najpewniej pobrał on na ten cel bliżej nieokreśloną zaliczkę. W Ciechanowie warsztat Niklosa rozpoczął wznoszenie zamku na surowym korzeniu, w bagnistym terenie w zakolu rzeki Łydyni (ryc. 7). Mury i baszty

${ }^{2}$ Stanisław Pazyra błędnie datował wystawienie owego rachunku na 1420 rok (Pazyra 1976, s. 249). Niekiedy też mylnie przywołuje się w tym kontekście rok 1429 (Kunkel 2006, s. 127).

3 Autor składa serdeczne podziękowania Tomaszowi Płóciennikowi za pomoc w thumaczeniu tego fragmentu.

${ }^{4}$ Brak takiego stwierdzenia także w powszechnie przywoływanym w tym kontekście artykule I. Galickiej pt. „Z mecenatu książęcego na Mazowszu” (Galicka 1984, s. 63-74). 


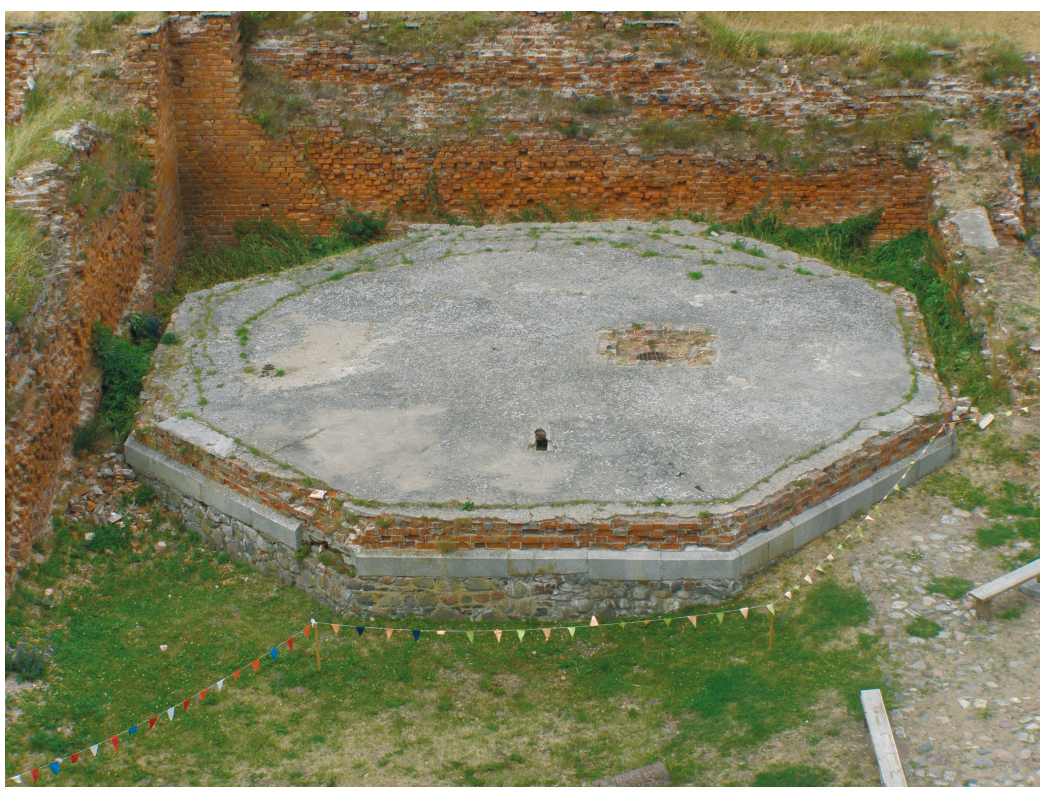

Ryc. 6. Radzyń Chełmiński. Relikty wieży głównej (fot. P. Lasek)

Fig. 6. Radzyń Chełmiński. Relics of the main tower (photo by P. Lasek)

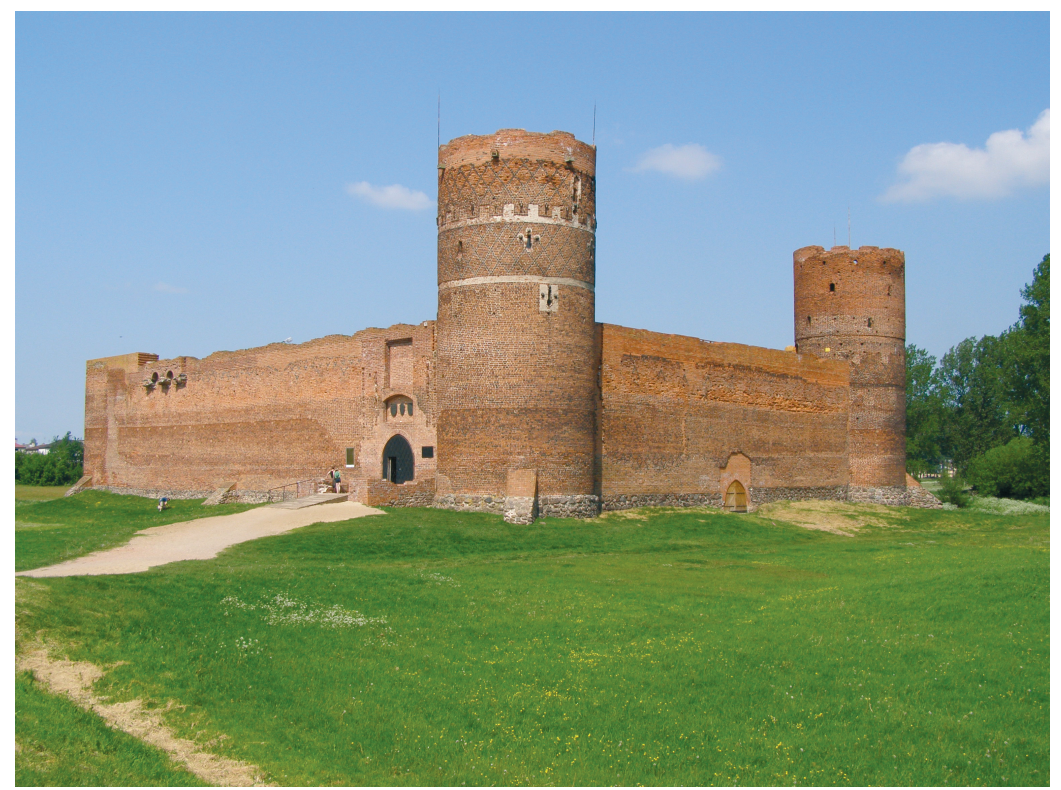

Ryc. 7. Ciechanów. Zamek (fot. P. Lasek)

Fig. 7. Ciechanów. Castle (photo by P. Lasek) 
wymurowano do wysokości około 7,7 m, po czym budowę z niewiadomych przyczyn przerwano. Izabela Galicka przypuszczała, że łączyło się to z błędem Niklosa w ocenie wiosennych wylewów Łydyni, w rezultacie czego woda zalała wznoszony zamek, a jego zwolniono z funkcji szefa budowy. Następnie prace kontynuowano już po zgonie Janusza I (Galicka 1968, t. 1, s. 89). W Liwie Niklos miałby rozpocząć budowę książęcego zamku na surowym korzeniu, wśród bagien i mokradeł w widłach rzek Czerwionki i Liwca. Realizacja ta miała rzut czworoboku zbliżonego do kwadratu, z budynkiem bramnym w formie otwartej do wnętrza zamku baszty, równej wysokości murów obwodowych, wysuniętej przed lico muru północno-zachodniego (ryc. 8). Wewnątrz zaplanowano dwa równoległe budynki, większy - dostawiony na całej długości do muru północno-wschodniego, mniejszy - przy murze południowo-zachodnim; rozdzielał je niewielki dziedziniec. Wnoszenie budowli z niejasnych powodów przerwano, po czym prace kontynuowano w 2 . ćwierci XV wieku, kiedy to dokończono budowę murów obwodowych i baszty bramnej, chronionej mostem zwodzonym (Galicka 1968, t. 2, s. 78-80). Wreszcie warsztat Niklosa miałby rozpocząć także budowę zamku czerskiego (ryc. 9), który - wedle I. Galickiej - łączą z Liwem i Ciechanowem wyraźne cechy warsztatowe i stylistyczne (Galicka 1968, t. 1, s. 81). Zdaniem badaczki w Czersku warsztat Niklosa zdążył wznieść mury wież cylindrycznych do wysokości 2,5 m oraz czworoboczną wieżę bramną do wysokości $12-13 \mathrm{~m}$, po czym z niewiadomych przyczyn miała miejsce chwilowa przerwa w budowie. Prace kontynuowano, ale przy użyciu innych wymiarów cegły, wznosząc mury i baszty na wysokość około $8 \mathrm{~m}$ i wieńcząc je krenelażem. Tak ukształtowany zamek miałby powstać jeszcze przed zgonem Janusza I w 1429 roku (Galicka 1968 , t. 2, s. 58-60).

Obserwowane we wszystkich wymienionych wyżej obiektach tajemnicze przerwanie robót I. Galicka połączyła ze zwolnieniem Niklosa z funkcji „głównego architekta" w służbie książęcej (Galicka 1968, t. 1, s. 89-90). Jednocześnie badaczka ta domniemywała, że w związku z tym faktem murator musiał zwrócić zleceniodawcy wspomnianą wyżej kwotę 57 kop groszy (Galicka 1968, t. 2, s. 20-21). Mimo zaznaczenia, że najpewniej warsztat Niklosa nigdy nie ukończył rozpoczętych dzieł w pierwotnie przewidzianej formie, I. Galicka podjęła próby szukania analogii dla pierwotnych koncepcji zamków w Ciechanowie, Czersku i Liwie (Galicka 1968, t. 1, s. 85). Dwa pierwsze rozpatrywane były w kontekście krzyżackich obiektów w Bytowie, Świeciu i Nidzicy oraz powstałego z inicjatywy Władysława Jagiełły zamku w Dybowie. Natomiast zamek liwski badaczka kojarzyła z realizacją Witolda w Trokach.

Powyższe spostrzeżenia stały się pretekstem do dalszej naukowej dyskusji, w toku której część badaczy odniosła się krytycznie do zaproponowanych przez I. Galicką periodyzacji najstarszych etapów powstawania zamków Janusza I (przede wszystkim w Ciechanowie i Czersku). W stosunku do zamku 


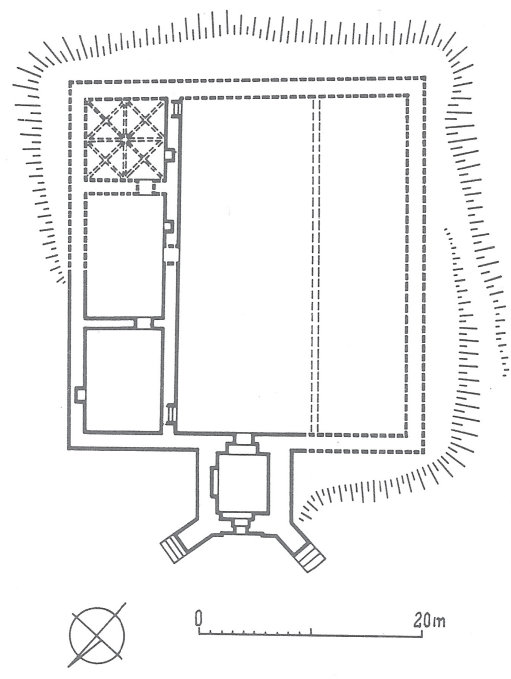

Ryc. 8. Liw. Zamek - rzut budowli w XV-XVI wieku; częściowa rekonstrukcja (rys. R. Kunkel; Zbiory Fotografii i Rysunków Pomiarowych Instytutu Sztuki PAN, nr inw. RP13465)

Fig. 8. Liw. Castle - plan of buildings in the $15^{\text {th }}-16^{\text {th }}$ centuries; partial reconstruction (drawing by R. Kunkel, The Collection of Photographs and Measurement Drawings of the Institute of Art of the Polish Academy of Sciences, inv. No. RP13465)

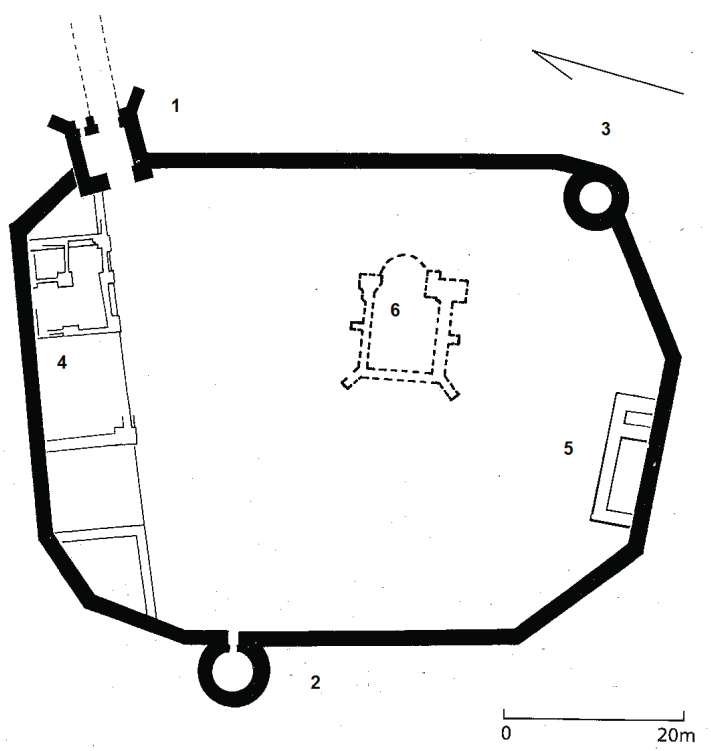

Ryc. 9. Czersk. Rzut ruin zamku (wg Kajzer, Kołodziejski, Salm 2001)

Fig. 9. Czersk. Plan of the castle ruins (after Kajzer, Kołodziejski, Salm 2001) 
czerskiego Tadeusz Zagrodzki wysunął hipotezę, że obiekt powstał w latach 1398-1406 oraz, że realizował go ten sam warsztat, co kolegiatę św. Jana w Warszawie, najpewniej zresztą także zatrudniony wcześniej w domenie krzyżackiej (Zagrodzki 1996, s. 42).

Natomiast konstatacje I. Galickiej co do początków zamku ciechanowskiego zanegowali R. Małowiecki (1992, s. 77-79), Aleksander Kociszewski (2006a, s. 19; 2006b, s. 92), ostatnio zaś Marek Piotrowski (2012, s. 8), zarzucając badaczce, że wprowadzona przez nią chronologia i atrybucja najstarszego etapu budowy obiektu opiera się na nikłych podstawach źródłowych i materiałowych, tymczasem w decydujący sposób zaważyła na wynikach dotychczasowych badań archeo- i architektonicznych, wypaczając ich wyniki. Jednocześnie nie wchodzono w polemikę z samą kwestią proweniencji warsztatów wznoszących wspomniane zamki mazowieckie, czy też pochodzeniem i kwalifikacjami samego Niklosa (por. choćby Postek 2008, s. 17; Sieradzan 2008, s. 579-581). Jedynie R. Kunkel, odnosząc się do specyficznych cech opisywanej grupy mazowieckich zamków, skonstatował, że choć oczywistym faktem jest wpływ architektury zakonu krzyżackiego na sąsiednie regiony, to jednocześnie przypisywanie en masse ich powstania oddziaływaniu wzorców z Prus jest błędem. Badacz ten zauważył, że zarówno zamki z terenów państwa zakonnego (wyjąwszy większość obiektów określanych mianem ,zamków konwentualnych”), jak i znaczna część zamków mazowieckich, nie wykraczają poza standard tego typu budowli, składającej się z mniej lub bardziej regularnego obwodu obronnego, domu mieszkalno-urzędowego i wieży. Także i technika ich wykonania (cegła w wątku tzw. gotyckim, na wysokim kamiennym podmurowaniu) jest charakterystyczna dla większości tego typu obiektów na Niżu Środkowoeuropejskim (Kunkel 2006, s. 133). Typ ten w znacznej mierze odpowiada wydzielonej przez Tomasza Olszackiego grupie kazimierzowskich „zamków administracji państwa” (określanych przez niego mianem „kaszteli kazimierzowskich”), będących - wedle tego badacza - późną redukcją regularnego europejskiego zamku kasztelowego, a charakterystycznych przede wszystkim dla Wielkopolski (Olszacki 2013a, s. 118). Z kolei R. Kunkel zauważył, że w dotychczasowej literaturze przedmiotu przeceniano wpływy architektury państwa zakonnego, zarówno na polu architektury sakralnej, jak i architecturae militaris. Jednocześnie R. Kunkel stawia niezwykle istotne - z punktu widzenia opisywanej problematyki - pytania badawcze, między innymi o autorstwo zasobu form stosowanych w działach architektury Zakonu oraz kwestie przeniesienia na teren Mazowsza działalności zespołów budowalnych z Prus po 1410 roku (Kunkel 2006, s. 175). Wreszcie badacz ten zaakcentowat niezwykle istotny fakt, że obecności muratorów pruskich na Mazowszu (poza Warszawą) znajduje nikłe odbicie w źródłach pisanych. Zdecydowanie lepiej wypadli w tej mierze przybysze z Wielkopolski. Jednocześnie specjaliści mazowieccy notowani są na terenie tej prowincji Korony przy różnych pracach budowlanych (Kunkel 2006, s. 133). 
Dążąc do podsumowania niewątpliwe ważnego problemu badawczego, jakim są korelacje zamków mazowieckich z architekturą zakonu krzyżackiego, zaznaczyć wypada, że stan naszej wiedzy na temat chronologii i przekształceń większości zamków mazowieckich wciąż jest niewystarczający. Zwłaszcza brak precyzyjnego datowania takich obiektów jak zamki w Płocku czy Rawie Mazowieckiej utrudnia stawianie hipotez na temat ich analogii formalnych. W przypadku Płocka wzniesienie na tamtejszym zamku wielobocznej wieży, w dodatku bramnej, mogło przebiegać równolegle z realizacją analogicznych obiektów na zamkach krzyżackich, takich jak Toruń (oktagonalna wieża główna powstała tam w 1. ćwierci XIV wieku - por. Wasik 2016, s. 251) czy Radzyń Chełmiński (Wasik 2016, s. 292-295). To samo dotyczy też „flagowych” realizacji, przypisywanych Januszowi I (Ciechanów, Czersk, Liw). Analiza murów obiektów rzeczywiście ujawnia kilka faz budowlanych, z których najstarsza, a więc zapewne pochodząca z czasów Janusza I, wydaje się pod wieloma względami unikalna. W Ciechanowie, Czersku i Liwie wzniesiono mury na wysokość kilku metrów, następnie zaś miała miejsce - wyraźnie widoczna - przerwa budowlana, po której kontynuowano dzieło, ale już z nieco innej wielkości cegły i przy odmiennej jakości murarskiego rzemiosła (Galicka 1968, t. 1, s. 89-90). Brakuje jednak jakichkolwiek pewnych dowodów, pozwalających łączyć opisaną sytuację z osobą muratora Niklosa. Wspomniana wzmianka z „Metryki Księstwa Mazowieckiego” ani nie dowodzi, że ów Niklos był głównym budowniczym książęcym, ani też nie precyzuje, za jakie prace otrzymał wynagrodzenie oraz czy ukończył swe dzieło (Metryka, t. 1, nr 8, s. 3). Można istotnie za I. Galicką przyjąć - jak choćby uczynił to Roman Postek (2008, s. 17) - że murator Niklos otrzymał od księcia zaliczkę na poczet bliżej nieokreślonych prac budowlanych. Biorąc pod uwagę wzmiankowaną w rozliczeniu kwotę, były to istotnie prace o rozległym zasięgu, najpewniej murarskie. Wysokość zobowiązania Niklosa wobec księcia - jak zaznaczono w rozliczeniu - była zależna od dokonywanych in situ pomiarów zakresu zrealizowanych prac (,o ile przypadkiem przez inne wymierzenie nie okazałoby się inaczej”), można domniemywać, że istotnie zakres wykonanych robót różnił się od pierwotnego planu. Jednocześnie wspominany tekst o prowadzonych „wymierzeniach" informuje nas, że w momencie spisywania rozliczenia zarówno obiekty w Ciechanowie, jak i w Liwie istniały już (przynajmniej częściowo) w formie kubaturowej, inaczej bowiem nie byłoby czego mierzyć. Prowadzi to do konkluzji, że murator Niklos ${ }^{5}$ między 1417 a 1429 rokiem pracował dla księcia Janusza I na zamkach w Ciechanowie i Liwie. Trudno określić, czy rozpoczął on ich budowę, czy też raczej kończył wcześniejsze prace lub dokonywał szeroko zakrojonego

\footnotetext{
${ }^{5}$ Niemiecko brzmiące imię wcale nie musi oznaczać, że pochodził on z ziem zakonu krzyżackiego. Było ono powszechne wśród przedstawicieli nacji niemieckiej, co przyznawała zresztą sama I. Galicka (1968, t. 1, s. 88). Fachowcy o tym imieniu występowali zresztą nie tylko w Prusach czy na Mazowszu; na przykład w 1425 roku murarz o imieniu Niklos został odnotowany na zamku w Sieradzu (Olszacki 2013, s. 29, przypis 92).
} 
remontu wymienionych obiektów. W każdym razie zakres wykonanych przez niego robót różnił się od tego umówionego z Januszem I, wobec czego specjalista najpewniej zatrzymał wynagrodzenie za zrealizowane już prace, resztę zaś musiał zwrócić do skarbca książęcego. Nie złamał chyba jednak rażąco postanowień swojego kontraktu, wówczas bowiem niewątpliwie książę zareagowałby surowiej. Mamy tu raczej do czynienia z typowym dla większości procesów inwestycyjnych w późnym średniowieczu i wczesnej nowożytności rozliczeniem między zleceniodawcą a jednym z wykonawców, który z niezależnych od niego przyczyn nie mógł w pełni zrealizować wyznaczonych mu celów.

Wobec braku jakichkolwiek dodatkowych danych na temat enigmatycznego muratora Niklosa, jego pochodzenia i zakresu przeprowadzonych prac, trzeba także zauważyć, że obserwowana przerwa w budowie zamków w Ciechanowie, Czersku i Liwie mogła mieć inne przyczyny. Być może mamy tu do czynienia jedynie z przerwą techniczną, potrzebną na wypalenie kolejnych partii cegły, co jednakże nie tłumaczy zmiany staranności wykonania wątku murów i innych wymiarów cegły. Należy wobec tego ostrożnie przyjąć, że istotnie doszło do zmiany warsztatu budowlanego. Przyczyny tego zjawiska na obecnym etapie badań są trudne do wyjaśnienia. Warto też zaznaczyć, że łączenie wzmianki o pracach prowadzonych przez Nikolosa na zamkach w Ciechanowie i Liwie z najstarszym etapem powstawania tych obiektów, jest całkowicie spekulatywne. Równie dobrze mógł on brać udział w pracach drugiej fazy budowy (po konflikcie z Zakonem?). Nie mamy też pewności, czy istotnie wszystkie opisywane obiekty ukończono za życia Janusza I. Być może było to już dzieło jego następców, choć rozbicie polityczne dzielnicy tego władcy oraz brak wydatków na budowę w księgach rachunkowych kolejnych książąt utrudniają udowodnienie tej hipotezy.

W tym miejscu warto także zaznaczyć, że każdy z opisanych wyżej zamków prezentuje odmienne założenia formalne i funkcjonalne. W przypadku Ciechanowa badacze podnosili jego znaczne walory reprezentacyjne, stanowiące widomy znak ostentacji władzy książęcej, przy jednoczesnej drugoplanowości elementów obronnych (Galicka 1968, t. 1, s. 85; Kunkel 2006, s. 133). Jednocześnie jednak już I. Galicka zauważyła, że realizację pierwotnej koncepcji zamku najpewniej przerwano, a dalsze prace budowlane prowadzone były szybko, w obliczu narastającego zagrożenia ze strony Krzyżaków (Galicka 1968, t. 1, s. 91). Na poparcie tej hipotezy badaczka wskazywała fakt, że gdyby pierwotnie planowano w Ciechanowie wzniesienie jedynie kilkumetrowej wysokości murów i baszt, to trudno wytłumaczyć, dlaczego dla czworoboku murów tego zamku przewidziano od początku istnienie wzmacniających przypór. Dotyczy to także baszt bramnych zamków w Czersku i Liwie, również ujętych w narożach masywnymi przyporami (Galicka 1968, t. 1, s. 91).

Być może w przypadku Ciechanowa istotnie odstąpiono od pierwotnej, czasochłonnej i kosztownej koncepcji architektonicznej na rzecz szybkiego 
zakończenia prac, zapewne pod presją nadchodzącego konfliktu z zakonem krzyżackim. Tłumaczyłoby to dążenie budowniczych do realizacji w pierwszym rzędzie obwodu obronnego, zaś dopiero w dalszej kolejności zaplanowanego pałacu książęcego. Warto jednak zauważyć, że w Ciechanowie także kolejna rozbudowa, łączona z czasami panowania księcia Bolesława IV (Lewicka 2008, s. 190), niewiele zmieniła sylwetę i układ zamku (niskie, przysadziste baszty w części południowej, nieprzekraczające wysokości murów kurtynowych). Trudno więc snuć rozważania, na ile zrealizowana forma zamku „,nieproporcjonalnie niskiego”, o basztach pozbawionych strzelnic była „odbiciem koncepcji Janusza realizowanej przez Niklosa" (Galicka 1968, t. 1, s. 91). To samo dotyczy także budowli w Czersku, gdzie również wzniesiono niskie, pozbawione otworów strzelniczych baszty, następnie sukcesywnie podwyższane (Zagrodzki 1996, s. 43).

Możliwe, że nigdy nie dowiemy się, jakie cele przyświecały budowniczym zamków w Ciechanowie i Czersku. Stworzyli oni dzieła enigmatyczne, pozbawione bezpośrednich analogii. Izabella Galicka dostrzegała wprawdzie podobieństwo zamku w Ciechanowie do tego w Nidzicy (ryc. 10), a wręcz twierdziła, że właśnie na tym obiekcie oparta była koncepcja architektury ciechanowskiego castrum, co uprawdopodabniać miał fakt nadania przez Jagiełłę obronnej siedziby w Nidzicy Januszowi I, w obliczu jego zasług na polach grunwaldzkich (Galicka 1968, t. 1, s. 94). Jak jednak słusznie zauważył R. Kunkel, obiekt w Nidzicy jest od zamku ciechanowskiego „mniejszy i zdecydowanie mniej reprezentacyjny” (Kunkel 2006, s. 133). Badaczka analizowała także architekturę zamków Janusza I (zwłaszcza Ciechanowa) w kontekście krzyżackich założeń w Nidzicy, Świeciu, a także późniejszego prokuratorskiego zamku w Bytowie (ryc. 11), podnosząc zastosowanie we wszystkich tych obiektach podobniej koncepcji baszt, flankujących mury kurtynowe (Galicka 1968, t. 1, s. 95; Galicka, Sygietyńska 2006, s. 540). Jednakże warto tu zauważyć, że w przypadku obu baszt zamku ciechanowskiego (ryc. 12), jak też baszty południowo-wschodniej w Czersku, mamy do czynienia z dziełami, które nie zostały w pełni wysunięte przed lico murów obronnych (w Czersku baszta znalazła się niemal wewnątrz obwodu!), w związku z czym nie mogły zapewnić pełnego ostrzału bocznego, chroniącego przedpole i podstawę murów przed atakującymi. O ile w przypadku baszty czerskiej znalazła się ona w peryferyjnym i naturalnie bronionym obszarze castrum, to baszty w Ciechanowie, zgodnie z obowiązującym obecnie stanem wiedzy, miały jakoby bronić pierwotniej bramy na osi kurtyny południowej. W rzeczywistości ich usytuowanie sprawiało, że właśnie bezpośredni rejon bramy pozbawiony był niemalże osłony z flanki. Taka sytuacja, w połączeniu z brakiem jakichkolwiek śladów umocnień nad ową domniemaną bramą południową, każą ponownie wziąć pod rozwagę podnoszone przez R. Małowieckiego wątpliwości co do jej funkcji jako przelotu bramnego (Małowiecki 2006, s. 139-146). 


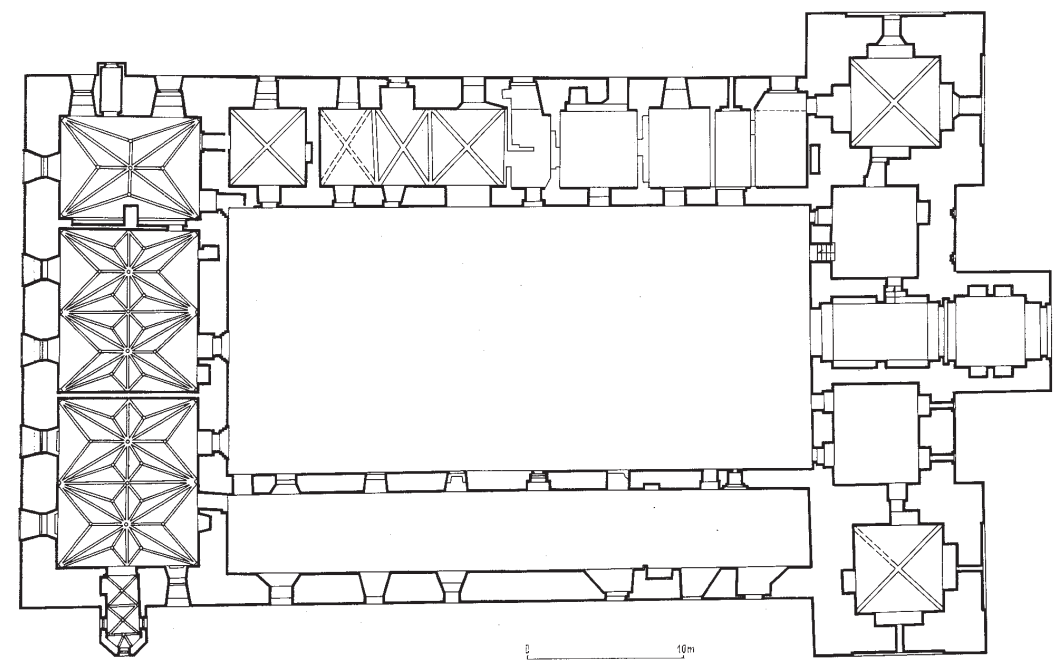

Ryc. 10. Nidzica. Zamek - rzut piętra; częściowa rekonstrukcja (rys. B. Kosińska; Zbiory Fotografii i Rysunków Pomiarowych Instytutu Sztuki PAN, nr inw. RP13691)

Fig. 10. Nidzica. Castle - storey plan; partial reconstruction (drawing by B. Kosińska, he Collection of Photographs and Measurement Drawings of the Institute of Art of the Polish Academy of Sciences, inv. No. RP13691)

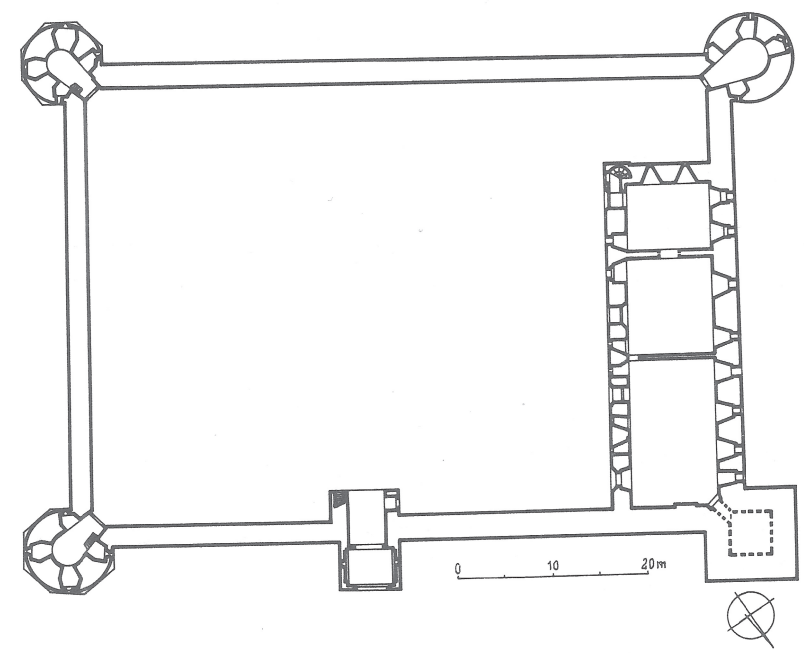

Ryc. 11. Bytów. Rzut zamku, częściowa rekonstrukcja (rys. F. Szymański; Zbiory Fotografii i Rysunków Pomiarowych Instytutu Sztuki PAN, nr inw. RP11164)

Fig. 11. Bytów. Plan of the castle; partial reconstruction (drawing by F. Szymański; he Collection of Photographs and Measurement Drawings of the Institute of Art of the Polish Academy of Sciences, inv. No. RP11164) 


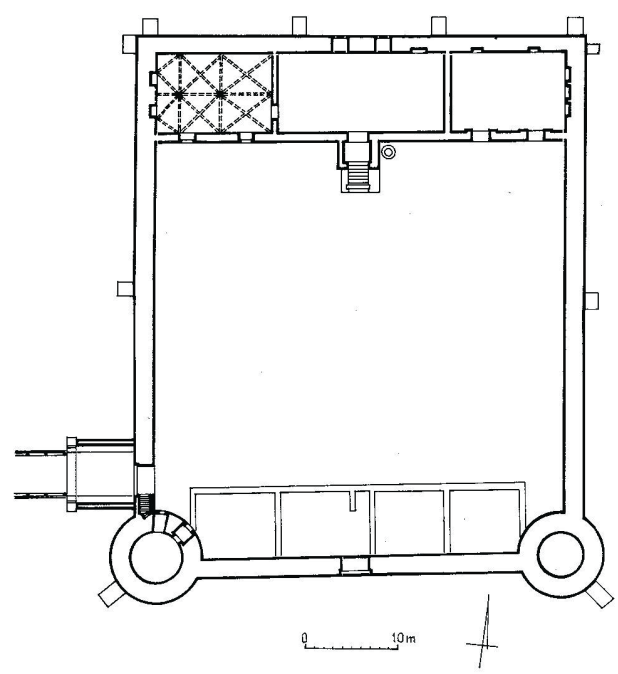

Ryc. 12. Ciechanów. Rzut zamku, częściowa rekonstrukcja (rys. R. Kunkel; Zbiory Fotografii i Rysunków Pomiarowych Instytutu Sztuki PAN, nr inw. RP11269)

Fig. 12. Ciechanów. Plan of the castle; partial reconstruction (drawing by R. Kunkel, he Collection of Photographs and Measurement Drawings of the Institute of Art of the Polish Academy of Sciences, inv. No. RP11269)

Poszukiwania potencjalnych analogii dla pierwotnej architektury zamków w Ciechanowie i Czersku wykraczają poza zakres niniejszego artykułu. Niemniej zaznaczyć należy, że dotychczas, prócz realizacji z ziem Zakonu, wskazywano w tym względzie również zamki wzniesione w Wielkim Księstwie Litewskim (np. Lida, Krewo, Miedniki), z zastrzeżeniem, że różni je od zamków mazowieckich zarówno technika budowy, jak i ich rozbudowana funkcja refugialna (Galicka 1968, t. 1, s. 94). W kontekście zamku w Ciechanowie R. Małowiecki (2006, s. 141) oraz R. Kunkel (2006, s. 133) wskazali też związki architektury tego obiektu z zamkami w Italii (np. Castello Sforzesco w Mediolanie). Ten wątek winien stać się przedmiotem innych analiz.

Natomiast architektura zamku w Liwie wyrasta z odmiennych założeń. Co zadziwiające, ta położona na peryferiach władztwa Janusza I realizacja została zaplanowana jako obiekt o znacznych walorach mieszkalnych. Należy go rozpatrywać w kontekście środkowoeuropejskich zamków dwudomowych, których specyficzne ukształtowanie uważa się za wynik ewolucji założeń obronno-mieszkalnych w kierunku zapewnienia wygodnej przestrzeni mieszkalnej (Skuratowicz 2006, s. 154-155). Za bliższą analogię realizacji w Liwie można by istotnie uznać - za I. Galicką - ceglany zamek w Trokach, wzniesiony na wyspie jeziora Galwe przez księcia Witolda, podobną koncepcję przestrzenną posiadały też dwudomowe realizacje z obszaru Niżu Polskiego, na przykład arcybiskupi 
zamek w Łowiczu, zbudowany w 3. ćwierci XIV wieku przez Jarosława Bogorię Skotnickiego lub nieco późniejsze Borysławice Zamkowe, wzniesione przez arcybiskupa Wojciecha Jastrzębca w latach 20. XV wieku oraz Gosławice koło Konina, powstałe z inicjatywy biskupa poznańskiego Andrzeja Łaskarza (na ten temat - por. Pietrzak 2005, s. 207-233; Kunkel 2006, s. 125).

Kończąc niniejszy wywód, należy stwierdzić, że - jak dotąd - nasz stan wiedzy nie pozwala na pełne potwierdzenie przytaczanych dotychczas opinii o przemożnym wpływie rozwiązań z terenu państwa krzyżackiego na architekturę zamków mazowieckich. Potwierdza to opinia R. Kunkla, który zauważył, że zarówno w architekturze świeckiej, jak i sakralnej nie sposób jednoznacznie wykazać przejęcia układów przestrzennych z terenów Pomorza (Kunkel 2006, s. 176). Niewykluczone jest wprawdzie znaczenie zamków krzyżackich dla upowszechnienia niektórych form architektonicznych (np. wieloboczne wieże główne), jednakże zagadnienie to znajdzie ostateczne wyjaśnienie dopiero po wnikliwym opracowaniu działalności inwestycyjnej Kazimierza Wielkiego w dziedzinie architecturae militaris, co umożliwi skorelowanie akcji budowlanej tego monarchy z podobnymi działaniami, podejmowanymi na Mazowszu. Co więcej, potrzebne są także dalsze badania, przede wszystkim źródłowe, zmierzające do lepszego rozpoznania początków większości zamków mazowieckich.

Nie znalazła też - jak dotąd - potwierdzenia w źródłach pisanych hipoteza o napływających jakoby na Mazowsze po 1410 roku warsztatach z terenów państwa krzyżackiego (na ten temat - por. także Kunkel 2006, s. 171). Nie bardzo zresztą wiadomo, przy jakich inwestycjach miałyby one pracować, bowiem w świetle wyników dotychczasowych badań większość zamków mazowieckich istniała już przed wybuchem konfliktu z Zakonem, dotyczy to także obiektów w Ciechanowie, Czersku i Liwie (być może niezrealizowanych wedle pierwotnej koncepcji lub nie w pełni ukończonych, ale najpewniej rozpoczętych przed 1410 rokiem). Natomiast jeśli chodzi o kościoły, to katalog gotyckich budowli sakralnych na Mazowszu, opracowany przez R. Kunkla, wymienia zaledwie kilka realizacji powstałych w 2.-3. dekadzie XV stulecia, przy czym są to niemal bez wyjątku niewielkie fundacje szlacheckie, o niepewnym datowaniu (Leszno - po 1420 roku, Łęg - 1. ćwierć XV stulecia; Kunkel 2006, s. 255, 257). Fundacje sakralne Janusza I (kolegiata w Warszawie - początek budowy korpusu najpewniej około 1402 roku, Nowogród Łomżyński - po 1409 roku; Kunkel 2006, s. 280, 343) mogły być jedynie kończone po ustaniu działań wojennych. W tym kontekście warto jeszcze zwrócić uwagę na fakt, że w rezydencjonalnym mieście książęcym, jakim był Ciechanów, murowany kościół gotycki powstał dopiero w XVI wieku (konsekracja w 1551 roku; Kunkel 2006, s. 202). Czy istotnie czekano by z tym dziełem tak długo, mając do dyspozycji wielu wykwalifikowanych pracowników z nieodległego państwa zakonnego? W dodatku, wobec rzekomego upadku tamże ruchu budowlanego, szukających pilnie zatrudnienia, a więc zapewne 
konkurencyjnych cenowo? Nie wydaje się to prawdopodobne i choć nie można wykluczyć, że istotnie po zakończeniu Wielkiej Wojny z zakonem krzyżackim działały na Mazowszu warsztaty budowlane z ziem krzyżackich, to dla ukończenia budowy kilku zaledwie inwestycji nie była chyba potrzebna ich liczna ,rezerwowa rzesza" (Galicka 1968, t. 1, s. 86).

Oczywiście spotykamy się w źródłach pisanych ze śladami działalności na Mazowszu specjalistów budowlanych z krzyżackich Prus, jak choćby wzmiankowany w 1475 roku murator Nikel, najpewniej gdańszczanin, czy - pochodzący także z Gdańska - Michael Enkinger (Słownik architektów i budowniczych 2016, s. 128-129, 336). Należy jednak podkreślić, że dla uzyskania pełnego obrazu ewentualnego wpływu specjalistów z terenu państwa zakonnego w Prusach na kształt architektury mazowieckiej niezbędne jest właściwe rozpoznanie ich działalności w ojczyźnie. Ostatnio Marian Arszyński skonstatował, że funkcjonowały one głównie w oparciu o organizacje cechów miejskich, skąd zatrudniane były do wykonywania zleceń różnorodnych inwestorów - zakonu krzyżackiego, miast, wreszcie zaś także zleceniodawców zagranicznych, w tym z Mazowsza (Arszyński 2016, s. 200, 204-210). Jeśli przyjąć ten punkt widzenia, to należałoby uznać, że trudno mówić o specyficznie krzyżackich warsztatach budowlanych, przenoszących modele architektury, rozwiązania konstrukcyjne i artystyczne Zakonu na sąsiednie ziemie. Mielibyśmy raczej do czynienia z kolejną, tym razem pruską odsłoną szeroko pojętej sztuki pobrzeży Bałtyku w dziedzinie architektury posługującej się sprawnie budulcem ceglanym. Jej miejscowa odmiana realizowana była przez grono specjalistów z dużych ośrodków miejskich, działających na zasadach konkurencji rynkowej, przy różnych przedsięwzięciach i dla różnych zleceniodawców, do których potrzeb, możliwości inwestycyjnych oraz horyzontów umysłowych zleceniobiorcy musieli się za każdym razem dostosowywać. Taki stan rzeczy mogą potwierdzać wyniki badań Bogusza Wasika nad architekturą kościoła, zamku i murów obronnych Kowalewa Pomorskiego. Badacz ten skonstatował, że przy realizacji kościoła pw. św. Mikołaja oraz zamku mogły działać aż dwa warsztaty budowlane, z których jeden, o wyższych kwalifikacjach, pracował też najprawdopodobniej przy realizacji kościoła parafialnego w pobliskiej wsi Chełmonie. Bogusz Wasik wyodrębnił także jeszcze jeden zespół specjalistów, który realizował mury obronne Kowalewa oraz - powiązane z nimi - południowe podzamcze (Wasik 2017, s. 79-84).

Warto tu jednakże zaznaczyć, że poczynione przez B. Wasika spostrzeżenia, niewątpliwie wartościowe badawczo, oparte zostały w dużej mierze na obserwacji wątków murów in situ. Sama zaś analiza murów nie może nam, niestety, dostarczyć pełnych informacji o pochodzeniu warsztatu murarskiego ani też o sposobie jego organizacji czy genezie zastosowanych rozwiązań formalnych. Uwaga ta jest o tyle istotna, że część badaczy neguje punkt widzenia M. Arszyńskiego, dowodząc, że zakon krzyżacki przywiązywał większą niż dotychczas sądzono 
uwagę do realizowanych w jego domenie dzieł architektury obronnej. Jeszcze przed wydaniem publikacji tego badacza w 2010 roku Marian Kutzner pisał o architekturze tzw. zamków konwentualnych: „Program tych budowli został najpewniej opracowany w kręgu centralnej administracji zakonnej, zapewne w środowisku mistrzów krajowych, rządzących Prusami w latach 60. XIII. Liczne źródła dziejowe bowiem wyraźnie sugerują, iż decyzje budowy nowych zamków zapadały w kancelarii zarządcy kraju, który nie tylko zapewniał wystarczający dopływ pieniędzy i pomoc materialną w realizacji całego przedsięwzięcia, lecz także słał na plac budowy swych wykonawców zaopatrzonych w instrukcje oraz [...] plan budowy. Administracja Zakonu w Prusach posiadała już najpewniej od początku 4. ćwierci wieku XIII własne zespoły wykonawcze, umożliwiające egzekwowanie właściwej wizji architektonicznej" (Kutzner 2010, s. 252). Ostatnio w recenzji wspomnianej wyżej pracy M. Arszyńskiego na opisywaną problematykę zwrócili uwagę historycy - Sławomir Jóźwiak i Janusz Trupinda (Jóźwiak, Trupinda 2016, s. 367-378). Wypomnieli oni M. Arszyńskiemu brak znajomości najnowszych wyników badań, wskazujących jednoznacznie na istnienie w administracji krzyżackiej specjalnych komórek, specjalizujących się w obsłudze finansowej, ale także i organizacyjnej przedsięwzięć budowalnych Zakonu (Jóźwiak, Trupinda 2015, s. 239-263). Co więcej, wedle tych badaczy władze krzyżackie ingerowały nie tylko w kształt i formę architektoniczną nadawaną ich siedzibom obronnym (co jest dość oczywiste), ale też wpływały na kształt i formę realizacji miejskich czy też wiejskich kościołów parafialnych (Jóźwiak, Trupinda 2016, s. 373). W kontekście tych rozważań problem proweniencji i zasad działania warsztatów i specjalistów budowlanych w Prusach wymaga dalszych badań. Wydaje się, że problematyka ta jest bardziej skomplikowana niż dotychczas sądzono, a przedstawiciele zakonu krzyżackiego mogli mieć większy wpływ na powstające na ich ziemiach inwestycje także poprzez narzucanie konkretnych koncepcji formalnych oraz dobór odpowiednich realizatorów swoich zamierzeń. Co więcej, rozwiązania te były następnie stosowane w zbliżonej formie w siedzibach biskupich (Majewski, Wasik, Wiewióra 2014, s. 64) .

Jeśli tak było w istocie, należy wątpić, czy Zakon udostępniałby owych „własnych” specjalistów do realizacji obiektów obronnych za granicą, w dodatku na przykład dla Janusza I Starszego, sojusznika wrogiej państwu zakonnemu monarchii jagiellońskiej (Galicka 1984, s. 70-71; Wilska 1986, s 17). Obok warsztatów specyficznie „krzyżackich”, a więc wytypowanych do konkretnych zadań przez władze Zakonu, funkcjonowali także cechowi budowniczowie miejscy i oni to właśnie byli grupą potencjalnych zleceniobiorców dla inwestorów z sąsiednich

\footnotetext{
${ }^{6}$ Niemniej B. Wasik twierdzi, że na zamkach w Wąbrzeźnie i Lubawie, powielających swym układem wzorce formalne zamków konwentualnych, przebieg prac był nieco odmienny od standardów stosowanych przy budowie założeń krzyżackich (Wasik 2014, s. 208-209). Może to świadczyć o wykorzystaniu odmiennego warsztatu, realizującego wedle własnych umiejętności i przyjętej praktyki wyznaczony model budowli.
} 
państw. Nie zawsze zresztą realizujących swe dzieło z pożądanym skutkiem. Warto tu w tym kontekście przywołać casus Szubina, a więc ceglanego zamku nizinnego, powstałego w podobnym horyzoncie czasowym oraz warunkach topograficznych i materiałowych, jak realizacje mazowieckie, w dodatku będącego siedzibą Sędziwoja z Szubina, którego ambicje, a chyba i możliwości finansowe zapewne niewiele ustępowały książęcym (Gąsiorowski 1995, s. 493-503). Otóż w liście Sędziwoja z Szubina, napisanym między 1398 a 1402 rokiem i adresowanym do rajców toruńskich pojawiła się skarga na muratora z Torunia, pracującego wcześniej przy zamku szubińskim, który ,[...] castrum nostrum in Szubino muniendo murum nobis destruxit totaliter et defraudavit nos in labore municionis huiusmodi, ceterum kmetones nostros arestavit, pro qua arestacione per ipsum facta opportebat nos dare septem marcas" (KDW, nr 1822, s. 87). Jak więc widać, nie zawsze zatrudnienie specjalisty z ziem krzyżackich zapewniało wysokąjakość świadczonych usług i dobry poziom rzemiosła murarskiego.

\section{Bibliografia}

\section{Źródla}

KDW - Kodeks dyplomatyczny Wielkopolski, t. 11, wyd. A. Gąsiorowski i in., Poznań 1999.

Metryka - Metryka Księstwa Mazowieckiego z XV-XVI wieku, t. 1: Księga oznaczona nr 333 z lat 1417-1429, wyd. A. Włodarski, Warszawa 1918.

\section{Literatura}

Arszyński M.

2016 Organizacja i technika średniowiecznego budownictwa ceglanego w Prusach w kontekście europejskim, Malbork.

Bocheńska A.

2017 Początki Zamku Królewskiego w Warszawie, [w:] Początki murowanych zamków w Polsce do połowy XIV w., red. A. Bocheńska, P. Mrozowski, Warszawa, s. 147-160.

Dąbrowski J.

1949 Problem rekonstrukcji części gotyckiej zamku oraz przywrócenia zespołu wnętrz z czasów Władysława IV, Ochrona Zabytków, t. 4, s. 226-236.

Galicka I.

1963 Problematyka badań średniowiecznych zamków na Mazowszu, Biuletyn Historii Sztuki, t. 25, nr 2, s. 109-118. 
1968 Świeckie budownictwo książęce w dzielnicy Janusza Starszego Mazowieckiego, maszynopis rozprawy doktorskiej w Zbiorach Specjalnych Instytutu Sztuki PAN w Warszawie, sygn. 1784/D, Warszawa.

1984 Z mecenatu książęcego na Mazowszu, [w:] Mecenas, kolekcjoner, odbiorca. Materiały sesji Stowarzyszenia Historyków Sztuki, Katowice, listopad 1981 r., red. E. Kowalska, A. Marczak-Krupa, Warszawa, s. 63-74.

Galicka I., Sygietyńska H.

2006 Sztuka gotycka (XIV-początek XVI w.), [w:] Dzieje Mazowsza, t. 1, red. H. Samsonowicz, Pułtusk, s. 533-567.

Gąsiorowski A.

1995 Zygmunt Luksemburski i Sędziwój z Szubina, czyli o węgierskich apanażach rodziny Ścibora ze Ściborza, [w:] Cracovia, Polonia, Europa. Studia z dziejów średniowiecza ofiarowane Jerzemu Wyrozumskiemu w sześćdziesiata piata rocznicę urodzin i czterdziestolecie pracy naukowej, red. F. Sikora, S. Szczur, Kraków, s. 493-503.

Gieysztor A.

1981 Warszawa gotycka, [w:] Jesteśmy w Warszawie. Miasto dawne i nowe, red. Z. Bartoszewska i in., Warszawa, s. 64-80.

Grzybkowski A.

1979 Zamek w Rawie Mazowieckiej. Zagadnienie fundacji i genezy, Kwartalnik Architektury i Urbanistyki, t. 24, z. 3, s. 195-216.

Jóźwiak S., Trupinda J.

2015 Das Amt des „,Bauleiters” (,,magister lapidum”; ,,magister laterum”; ,, steinmeister”, ,, czygelmeyster”, ,, muwermeister”) im Deutschordensstaat im 14. Jh. und in der ersten Hälfte des 15. Jh., Ordines Militares Colloquia Torunensia Historica. Yearbook for the Study of the Military Orders, t. 20, s. 239-263.

2016 (rec.) Marian Arszyński, Organizacja i technika średniowiecznego budownictwa ceglanego w Prusach w kontekście europejskim, Wydawnictwo Muzeum Zamkowego w Malborku, Malbork 2016, ss. 405, Komunikaty Mazursko-Warmińskie, t. 2(292), s. 367-378.

Kajzer L.

2007 Zproblematyki wplywów budownictwa warownego Krzyżaków na zamki Niżu Polskiego, Archaeologia Historica Polona, t. 17, s. 259-273.

Kajzer L., Olszacki T.

2011 Mazowieckie zamkiw Gostyninie i Sochaczewie na tle problematyki zamków starościńskich Krzysztofa Szydłowieckiego, [w:] Fundacje kanclerza Krzysztofa Szydłowieckiego. Z dziejów budownictwa rezydencjonalno-obronnego na terenie dawnego województwa sandomierskiego. Materiały z sesji naukowej w ramach Europejskich Dni Dziedzictwa - Ćmielów 2007, red. W. Iwańczak, R. Kubicki, D. Kalina, Kielce-Ćmielów, s. 49-62.

Kąsinowski A.

2001 Zamek Warszawski a badania architektoniczne, [w:] Restytucja Zamku Królewskiego w Warszawie, red. T. Polak, Warszawa, s. 56-75. 
Kociszewski A.

2006a Karty do dziejów zamku w Ciechanowie, Studia Mazowieckie, t. 2(7), nr 1, s. $11-36$.

2006b Karty do dziejów zamku, Ciechanowskie Studia Muzealne, t. 4, s. 85-112.

Król A.

1971 Zamek Królewski w Warszawie od końca XIII wieku do roku 1944, wyd. 2, Warszawa.

Kunkel R.

1995 Mazowsze i Wielkie Księstwo Litewskie, [w:] Architektura gotycka w Polsce, red. T. Mroczko, M. Arszyński, t. 1, Warszawa, s. 83-92.

2006 Architektura gotycka na Mazowszu, Warszawa.

2007 Typologia średniowiecznych zamków ksią̇ęcych i możnowładczych na Mazowszu, Kronika Zamkowa, t. 1-2(53-54), s. 211-229.

Kutzner M.

2010 Propaganda władzy zakonu niemieckiego $w$ sztuce na terenie państwa zakonnego w Prusach, [w:] Fundacje artystyczne na terenie państwa krzyżackiego w Prusach, t. 2: Eseje, red. B. Pospieszna, Malbork, s. 238-268.

Lasek P.

2017 Początki zamków na Mazowszu w świetle nowszych badań, [w:] Początki murowanych zamków $w$ Polsce do połowy XIV w., red. A. Bocheńska, P. Mrozowski, Warszawa, s. 69-91.

Lewicka M.

2008 Konserwatorski problem ,rewaloryzacji” zamku w Ciechanowie, [w:] Ochrona zabytków architektury obronnej. Teoria a praktyka, red. M. Lewicka, Lublin-Warszawa, s. 184-203.

Lileyko J.

1995 Zamek książt mazowieckich, [w:] Architektura gotycka w Polsce, red. T. Mroczko, M. Arszyński, t. 2, Warszawa, s. 248.

Majewski M., Wasik B., Wiewióra M.

2014 Studia nad warsztatem budowlanym zamku biskupów chetmińskich w Wąbrzeźnie, Wiadomości Konserwatorskie, t. 38, s. 54-65.

Małowiecki R.

1992 Problemy początków zamku w Ciechanowie, Zapiski Ciechanowskie, t. 8, s. 77-93.

2006 Problem bramy południowej zamku w Ciechanowie, Studia Mazowieckie,

Mroczko T. t. 2(7), nr 1, s. 139-146.

1974 Ruch budowlany na ziemi chetmińskiej w XIII wieku, [w:] Sztuka i ideologia XIII wieku, materiaty sympozjum Komitetu Nauk o Sztuce PAN, Warszawa, 5 i 6 IV 1971 r., red. P. Skubiszewski, Wrocław, s. 281-332.

1986 Architektura, rzeźba, malarstwo, [w:] Sztuka Warszawy, red. M. Karpowicz, Warszawa, s. 10-41. 
Nierychlewska A.

2013 Zamki i dwory województwa rawskiego w późnym średniowieczu i czasach wczesnonowożytnych, Łódź.

Oborska I.

2001 Zamek Królewski w Warszawie - od koncepcji do realizacji. Lata 1954-1987, [w:] Restytucja Zamku Królewskiego w Warszawie, red. T. Polak, Warszawa, s. $76-100$.

Olszacki T.

2013a Kazimierzowskie zamki na Niżu Polskim: próba klasyfikacji, [w:] Interdyscyplinarne badania założé rezydencjonalnych i obronnych, red. P. Sypczuk, Studia i Materiały Archeologiczne, Suplement 2, Warszawa, s. 114-141.

2013b Zamek królewski w Sieradzu. Dzieje - badania-architektura, Sieradz.

Olszacki T., Różański A.

2018 Góra Zamkowa w Wyszogrodzie. Mazowiecki ośrodek władzy na przestrzeni dziejów, Poznań.

Pazyra S.

1976 Dzieje Ciechanowa i ziemi ciechanowskiej, Ciechanów.

Pela W.

2016 Wyniki badań archeologiczno-architektonicznych jako źródto poznawcze do dziejów Pultuska od XII do XVIII wieku, [w:] Dzieje Puttuska, t. 1: Do 1795 r., red. H. Samsonowicz, R. Lolo, Pułtusk, s. 11-44.

Pietrzak J.

2005 „Dwudomowe”, nizinne zamki średniowieczne i ich dziedzińce w prowincji Wielkopolskiej, Archaeologia Historica Polona, t. 15/1, s. 207-233.

2012 Zamek w Gostyninie. Dzieje budowlane w świetle przekazów archiwalnych i badań terenowych, Rocznik Gostyniński, t. 3, s. 9-44.

Piotrowski M.

2012 Fakty i mity ciechanowskiego zamku, Ciechanów.

Polak Z.

2011 Płock średniowieczny kontynuacja czy nowa jakość?, [w:] Płock wczesnośredniowieczny, red. A. Gołembnik, Warszawa, s. 311-378.

Postek R.

2008 Liw. Miasto i zamek, Warszawa.

Sieradzan W.

2008 Der Kulturtransfer zwischen dem Deutschen Ordensstaat und Masowien im Spätmittelalter, [w:] Mittelalterliche Kultur und Literatur im Deutschordensstaat in Preussen: Leben und Nachleben, red. J. Wenta, S. Hartmann, G. Vollmann-Profe, Toruń, s. 569-586.

Skuratowicz J.

2006 Piętnastowieczne prywatne zamki w Wielkopolsce, [w:] Wielkopolska-Polska-Europa. Studia dedykowane pamięci Alicji Karłowskiej-Kamzowej, red. J. Wiesiołowski, Poznań, s. 153-162. 
Stownik architektów i budowniczych

2016 Słownik architektów i budowniczych środowiska warszawskiego XV-XVIII wieku, red. P. Migasiewicz, H. Osiecka-Samsonowicz, J. Sito, Warszawa.

Teterycz-Puzio A.

2015 Bolesław II Mazowiecki. Na szlakach ku jedności (ok. 1253/58-24 IV 1313), Kraków.

Wasik B.

2014 Próba rekonstrukcji etapów budowy i układu przestrzennego zamku na podstawie wyników badań historycznych, archeologicznych i architektonicznych, [w:] Zamek biskupów chetmińskich w Wąbrzeźnie w'świetle badań archeologiczno-architektonicznych. Studia i materiaty, red. M. Wiewióra, Toruń, s. 207-214.

2016 Budownictwo zamkowe na ziemi chetmińskiej od XIII do XV wieku, Toruń.

2017 Zamek, kościół i mury miejskie w Kowalewie Pomorskim-kwestia XIV-wiecznych warsztatów budowlanych, Biuletyn Historii Sztuki, t. 79, nr 1, s. $71-85$.

Widawski J.

1970 Początki i rozwój murowanych obwarowań Warszawy przed epoka broni palnej, Kwartalnik Architektury i Urbanistyki, t. 15, z. 3, s. 239-252.

Wilska M.

1986 Ksiązę Janusz Starszy, Warszawa.

Zagrodzki T.

1956 Analiza rozplanowania Starego Miasta w Warszawie. Zagadnienie modularności i planu lokacyjnego, Kwartalnik Architektury i Urbanistyki, t. 1, z. 3, s. 225-265.

1996 Czersk. Zamek i miasto historyczne, Warszawa.

\section{MAZOVIAN CASTLES AND ARCHITECTURE OF THE TEUTONIC ORDER. A RECAPITULATION}

Keywords: Teutonic Order, castles, Mazovia, cultural relations, defensive architecture, Duchy of Mazovia.

Summary

In 2007 Leszek Kajzer published in the 'Archaeologia Historica Polona' an article devoted to the issue of the influence of defensive architecture of the Teutonic Order on the castles of the Polish Lowland. This eminent researcher of defensive and residential architecture stated then that 'although the motif of the architecture of Teutonic Order's castles on neighbouring fortified structures appears in almost all works devoted to their military architecture, these issues have not been thoroughly studied'. This article approaches such research needs. 
Most of the researchers emphasised topographic conditions characteristic of Mazovia and the lack of stone building material. This would bring the duchy's architecture closer to the north-European brick building, where the first role in the $14^{\text {th }}$ century was played by workshops commissioned by the Teutonic Order, which then influenced the areas of the Polish Lowland and Mazovian lands. The discussed defensive structures, apart from the technique of their walls' construction, would be also related to the Teutonic Order architecture's zone of influence by individual defensive and residential elements.

Relations with the architecture of the Teutonic Order were already marked in the case of the oldest masonry structures of the Warsaw castle, the so-called Grodzka Tower, as well as some elements of other Mazovian castles (a polygonal tower in Rawa Mazowiecka).

Izabella Galicka also indicated in her works the reference in 'Metryka Księstwa Mazowieckiego', informing about the financial settlement between the Duke Janusz I and an enigmatic builder Niklos for his work on castles in Ciechanów and Liw. According to I. Galicka, Niklos was an architect who came to Mazovia from the territory of the Teutonic Order. The researcher attributes his workshop to the implementation of the oldest building phases of castles in Ciechanów, Czersk and Liw.

However, the state of our knowledge about the chronology and transformations of most of the Mazovian castles is still insufficient. Especially the lack of precise dating of such structures as castles in Płock or Rawa Mazowiecka makes it difficult to put forward hypotheses concerning their formal analogies. In the case of Płock, the construction of a polygonal tower in the castle, and moreover the gate one, could have occurred parallel to the implementation of analogous structures on the Teutonic Order's castles, such as Toruń or Radzyń Chełmiński. The same applies to realisations attributed to Janusz I (Ciechanów, Czersk, Liw). The analysis of the structures' walls does indeed reveal several building phases, the oldest of which, probably coming from the times of Janusz I, seems unique in many respects. In Ciechanów, Czersk and Liw the walls were erected to a height of several metres, and then there was a visible construction break, after which the work was continued, but a slightly different size of brick and a different quality of masonry craft were implemented. However, there is no reliable evidence to associate the described situation with the person of the mason Niklos. The aforementioned reference from the 'Metryka Księstwa Mazowieckiego' does not prove that Niklos was the duke's main builder, nor does it specify the work he was paid for and whether he completed his work. One can indeed assume after I. Galicka that the mason Niklos received an advance payment from the Duke on account of unspecified construction works. Considering the amount mentioned, these were indeed works of wide range, probably masonry ones. The settlement indicated that the amount of Niklos's liability to the Duke depended on the in situ measurements of the work's range, hence it can be presumed that it was significantly different from the original plan. At the same time, the aforementioned text about the conducted 'measures' informs that at the moment of registering the settlement, both the structures in Ciechanów and in Liw existed (at least in part) in a cubic form, otherwise there would be nothing to measure. This leads to the conclusion that the mason Niklos (German sounding name does not necessarily mean that he came from the Teutonic Order territory) between 1417 and 1429 worked for the Duke Janusz I at castles in Ciechanów and Liw. It is difficult to determine whether he started to build them, or rather he finished previous works or carried out extensive renovation of the structures in question.

It is worth noting that each of the Mazovian castles described above presents different formal and functional foundations. In the case of Ciechanów, the researchers pointed out its considerable representational values, being a visible sign of ostentation of the du- 
cal authority, with the secondary role played by the defensive elements. Izbella Galicka perceived the similarity of the castle in Ciechanów to the structure in Nidzica, which, however, differs from the Ciechanów castrum by formal and workshop features. The researcher also analysed the architecture of the Janusz I castles (especially Ciechanów) in the context of the Teutonic Order's structures in Nidzica, Świecie, as well as of the later pfleger's castle in Bytow, raising the use of similar concept of towers flanking the curtain walls in all these structures. However, it is worth noting that in the case of both towers of the Ciechanów castle, as well as the south-eastern tower in Czersk, we deal with works which were not fully extended before the face of defensive walls (in Czersk the tower was almost inside the perimeter), therefore, they could have not provided full side fire, protecting the foreground and the base of the walls from the attackers. In relation to the castle in Ciechanów, Ryszard Małowiecki and Robert Kunkel also put forward the links of its architecture with castles in Italy (e.g. Castello Sforzesco in Milan). This topic should be subject to separate analyses.

It should be stated that - to date - our state of knowledge does not enable a full confirmation of the quoted opinions about the overwhelming influence of solutions from the territory of the Teutonic Order state on the architecture of Mazovian castles. This confirms the opinion of R. Kunkel, who noticed that both in secular and sacred architecture it is impossible to clearly indicate the influence of spatial arrangements from the areas of Pomerania. Although, the significance of the Teutonic Order's castles in popularisation of some architectural forms (e.g. polygonal main towers) cannot be ruled out, this issue will only be definitively clarified after a thorough study of Casimir III the Great investment activity in the field of architecturae militaris, which will enable the correlation of the construction action of this monarch with similar activities undertaken in Mazovia. It has to be added, that further studies are needed, primarily the source ones, aimed at better recognition of the origins of most of the Mazovian castles. 
